\title{
THE SOUTH AFRICAN ACT REVISITED - SOME CONSTITUTIONAL AND POLITICAL REFLECTIONS ON LESSONS LEARNT FROM THE CENTENARY OF THE UNION OF SOUTH AFRICA IN 1910
}

\author{
GE Devenish
}

BSc LLB LLD LLD

Senior Research Associate

University of KwaZulu-Natal (Durban)

\section{SUMMARY}

Just over a hundred years ago South Africa became a politically united state governed by the South Africa Act of 1909, which constituted the first constitution for a territory comprised of the four erstwhile British colonies of the Cape of Good Hope, Natal, the Transvaal and the Orange River Colony. This article revisits this historic constitution and attempts to revaluate its cardinal characteristics in the light of our subsequent constitutional and political development. This article also examines the constitutional and political configuration of the South Africa Act and how it came into being through a so-called National Convention and the part played by the prominent politicians and role players of the day. It examines the constitutional precedents that were available at the time. The crucial issues relating to the nature of the state that was to be established and why a unitary model and not a federation was adopted, are explained. It also considers the vexed question of the franchise and how a compromise was reached in this regard. Other important issues on which decisions had to be taken such as, inter alia, language, native and Indians affairs, are examined and evaluated. The article attempts to address certain important constitutional and political lessons that can be learnt from such an evaluation.

\section{INTRODUCTION}

Just over a hundred years ago South Africa became a politically-united state governed by the South Africa Act of 1909, which constituted the first constitution for a territory comprised of the four erstwhile British colonies of the Cape of Good Hope, Natal, the Transvaal and the Orange River Colony. This article revisits this historic constitution and attempts to revaluate its cardinal characteristics in the light of the country's subsequent constitutional and political development. There are important constitutional and political lessons to be learnt from such an evaluation. Furthermore, certain seminal aspects of the present South African Constitution of 1996, such as constitutional supremacy, can only be fully and contextually comprehended 
by comparing it with parliamentary sovereignty on which the South Africa Act was premised. The same applies, inter alia, to unitary and federal constitutional models of government, and constituency and proportional representation. A knowledge and understanding of the South Africa Act and some of its prejudicial and beneficial consequences, facilitates comparative constitutionalism. ${ }^{1}$ This article also examines some of jurisprudential and political ideas as well as the role of political leaders that influenced the configuration of the South Africa Act.

\section{THE ANGLO-BOER WAR AND THE PEACE OF VEREENIGING}

The Anglo-Boer war was a tragic and violent episode in the history of South Africa and it was to bequeath to several generations of White South Africans a legacy of intense bitterness, which was to influence the direction of political and constitutional change. The violence wrought by the war is poignantly spelled out by the eminent South African historian, Hermann Giliomee, as follows: "British troops wiped out about two thirds of the cattle herds on the farms in the old Boer Republics and burnt down between 30000 to 40000 houses. One tenth of the Boer population lost their lives."

The magnanimous treaty of Vereeniging brought to an end the protracted agony of the war on 31 May 1902, when the guns of war became silent. The treaty promised the vanquished Boers civil institutions and ultimately selfgovernment, ${ }^{3}$ and it held out the prospect of constitutional reform for the White inhabitants within the two Crown colonies. However, the highly contentious and vexed issue of the African franchise was deferred, pending the granting of responsible government to the defeated states. ${ }^{4}$ In both the Boer Republics, Africans and other people of colour had been denied the franchise. ${ }^{5}$ After the Boer war the British Government, under a Liberal Party Prime Minister, Mr Campbell-Bannerman, endeavoured to conciliate the Boers and hence did not press for the enfranchisement of Africans, with the result that the advent of responsible government under the British Crown which constituted a significant reform did not affect the status of people of colour in the two former republics. Metaphorically they were left out of the equation, based on the idea of conciliation between British and Dutch South Africans. This idea of conciliation was initiated by Campell-Bannerman, and

1 This is required by $\mathbf{s} 39$ of the Constitution, which states that when interpreting the Bill of Rights a court ...

(a) $\quad \ldots$

(b) must consider international law; and

(c) may consider foreign law.

2 See Giliomee "South Africa - Happy with a Broken Heart" 2 June 2010 The Witness.

3 Walker A History of Southern Africa (1965) 504. Article 7 of the Treaty of Vereeniging.

4 Article 8 of the Treaty of Vereeniging. "The question of granting of the franchise to natives will not be decided until after the introduction of self-government." See Eybers Select Constitutional Documents Illustrating South Africa History 1796-1910 (1918) 346. Note that this provision implied that a Coloured and Asian franchise was not ruled out.

5 Article 9 of the Constitution of the South African Republic provided that "The people desire to permit no equality between Coloured people and the White inhabitants, either in Church or State." See Eybers 364. 
then taken up by Botha and Smuts. ${ }^{6}$ Eighty years later De Klerk and Mandela were to embark on a far more comprehensive process of reconciliation between Blacks and Whites, giving rise to a political settlement in South Africa resulting in the interim and 1996 Constitutions.

\section{COLONIAL REFORM}

This meant that within the colonial framework of the time, the Whites in the two colonies were to enjoy the fruits of constitutional reform, that is, representative and responsible government, but all the Non-Whites were to continue to be subjected to a paternalistic, oligarchic and authoritarian system of government in which they had no part or say. This kind of reform had taken place in the Cape Colony, which involved a qualified non-racial franchise, in contrast with the colour bar that was adopted in the Transvaal and Orange River Colony. Such a colour bar constituted an ambivalent constitutional duality, which provided a democratic form of government for Whites and a rigid authoritarian form for Blacks, was to become part of South Africa's problematic constitutional legacy until the advent of democratic and non-racial government with the inception of the Interim Constitution in 1994. This was not in conflict with the political and moral thinking at the time. In this regard John Stuart Mill, one of great liberal thinkers of $19^{\text {th }}$ century Great Britain, declared "Despotism is a legitimate mode of government in dealing with barbarians, provided the end be their improvement". ${ }^{8}$

Although this form of government cannot be morally condoned in the contemporary world of today, it was a product of imperialism and colonialism, which dominated the manner in which European leaders and governments prejudicially perceived persons of colour in the world before the First World War. The period before the First World War was, par excellence, the age of the British Empire, which was characterized by the policy of imperial expansion and annexation. However, imperialism was based on a flawed moral belief that Europeans "considered the people of Africa and Asia to be racially inferior". "This was to have detrimental consequences for people in essentially in Asia and Africa.

\section{THE NATIONAL CONVENTION}

On account of the very considerable cultural and regional disparities encountered in the four British colonies it was initially "unquestioningly assumed"10 $^{\prime \prime}$ that the constitutional and political unification of South Africa

6 Hancock Smuts 1 The Sanguine Years (1962) Chapter 12 "Conciliation" 230-245.

7 See De Klerk "The Process of Political Negotiation: 1990-1993" in De Villiers (ed) Birth of a Nation (1994) 1-11.

8 Mill Utilitarianism, On Liberty and Representative Government (1910) 73.

9 See The World Book Encyclopedia Vol 10 (1992) 47.

10 Davenport South Africa A Modern History (1977) 164. See Hahlo and Kahn The Union of South Africa: South Africa The Development of its Laws and Constitution (1960) 119: "Up to 1908 , though there had been some supporters of unification such as Henry de Villiers and Merriman, few had believed that local sentiments and the size of the proposed new state would allow more to be accomplished than a federation with a strong central government on 
would of necessity have to take place by means of a genuine federation, involving an entrenched division of legislative and executive power between the component states and the central government, rather than a centralized unitary state, in order to secure an optimal devolution of authority, which could militate against the abuse of power that can take place so easily when power is concentrated in one particular location. However, during the latter part of the first decade of the $20^{\text {th }}$ century certain prominent political leaders began to propagate a unitary form of government cogently, rather than a federation. ${ }^{11}$ This form of government to a great extent encapsulated the ideas, both political and philosophical, of Smuts, and to a lesser extent Merriman. ${ }^{12}$ Union was compatible with Smuts's philosophy of holism as reflected in his book Holism and Evolution. ${ }^{13}$ The protagonists of federalism, such as Schreiner and Hofmeyr, citing the Canadian and Australian precedents, in effect, it is submitted, allowed the case for federalism to be lost by default. Moreover, that intrinsically federalism had much to commend itself and had been tried and tested in Australia and Canada.

In 1908 the economically powerful and politically influential Transvaal colony gave abrupt notice that it intended to withdraw from the customs convention which had its inception in $1903 .^{14}$ This was a political symptom of the intrinsic malady of the absence of a meaningful central authority to regulate the increasingly complex and competitive economic relationships between the colonies and to co-ordinate policy between colonies in regard to the so-called "Indian" and "native" questions. "It was plain, even as it had been plain in America in 1789, in Canada in 1867 and in Australia in 1900 that the country could not live without a central regulating power." ${ }^{15}$ The threatened withdrawal from the customs convention by the economically prosperous Transvaal colony, precipitated an Inter-colonial Conference in 1908 , at which it was unanimously decided that a National Convention should be convened for the purpose of endeavouring to effect the desired unification of South Africa. Constitutional change at the time was centripetal in nature and this tendency was to continue long after the advent of the Union, and contributed towards the decline and truncation of the powers of the provincial councils. This was proven to be most unfortunate, since the centralization of political power was to facilitate a most regrettable abuse of power, particularly after 1948, with the advent of the policy of Apartheid,

the lines of the 1877 Act. But then the Kindergarten with its "Closer union" movement and Merriman began drumming the advantages of unification: economy; flexibility; the elimination of the judiciary's testing right and with it the hateful prospect of political appointments to the Bench; security for the entire White population. The disadvantages of federation in Canada and Australia were stressed and often exaggerated. After the 1908 Conference sentiments elsewhere than in Natal began swinging towards unification. The warning voices of federalists like W P Schreiner were not heeded."

11 Davenport 164. See also Wilson and Thompson The Oxford History of South Africa Vol 2 (1978) 350; and Wiechers Staatsreg (1981) 196.

12 See Hancock (1962) Chapter 13 "Union” 246-268.

13 Hancock (1962) 305.

14 Walker 507.

15 De Kewiet A History of South Africa (1968) 149 and 150. The basic problem was that the four colonies were economically interdependent. Political separation impeded the prosperity and political harmony of the entire region. Political unification was therefore the answer to this problem. See Muller Five Hundred Years, A History of South Africa (1981) 372. 
under the National Party. Had the powers of the provincial councils been entrenched in the same manner as the Cape Province's franchise rights, giving rise to a quasi-federation, abuse of political power could have been mitigated and the constitutional and political history of South Africa may have been very different.

In essence the National Convention was concerned with the constitutional structure of the proposed new state, which was to determine and control "the distribution of power" ${ }^{16}$ Asians, Africans and Coloureds had no direct say in the discussions and deliberations of the Convention. Since the entire nation was not represented at the Convention, the term "National Convention" is therefore manifestly a misnomer. This was obviously unsatisfactory, since the South Africa Act, as the product of this so-called convention, was ultimately to facilitate constitutional retrogression and not reform. An authentic national convention was only to occur during the period of negotiations that emerged from Codesa, the process of political negotiation from 1990-1993 and the deliberations of the Constitutional Assembly from 1994-1996, resulting in the final, or 1996, Constitution. ${ }^{17}$ This was to give rise to a genuine autochthonous or indigenous constitution, being one that is home-grown or sprung from the native soil. ${ }^{18}$ This was obviously not the position with the South Africa Act of 1909, which was not indigenous and reflected imperial and colonial characteristics and was therefore allochtonous, that is, reflecting a foreign origin. ${ }^{19}$

The Cape delegates alone, representing all the voters in their colony in which there was a non-racial, but qualified franchise, could claim to speak on behalf of people of colour. Most of the delegates from the Cape, both Dutch and British, were imbued with the spirit and the merits of the Cape's meritorious liberal tradition, and earnestly desired the extension of the Cape's qualified, non-racial franchise to the northern provinces and the subsequent progressive enfranchisement of all people of colour. Such a tradition would indeed have constituted a fundamental reform for all concerned, but the delegates from the other colonies were vehemently opposed to such a prospect.

The exclusion of all persons of colour from participating in the National Convention meant that the South Africa Act was in essence a constitution devised exclusively by Whites and imposed on all the Non-whites of South Africa. In the colonial world order of 1910, the South Africa Act, carrying the imprimatur of the Imperial Parliament at Westminster, did not lack respectability or legitimacy. With the passing of the old colonial order, after the Second World War and the onset of decolonization, the South Africa Act was to be viewed in a different constitutional perspective, in that it had created a highly oligarchic and racist constitution, which is apparent from the population figures of the time. The total population in 1910 was approximately 6000000 persons of whom 4000000 were Africans, 500000 were Coloured persons and 150000 Indians. The remaining

16 Davenport 168. See Karis and Carter From Protest to Challenge (1978) 52, Volume 1, documents 14,15,16, 17 and 18 dealing with "African Fears at the Prospect of Union".

17 See Rautenbach and Malherbe Constitutional Law (1996) 16.

18 See Wheare Constitutional Structure of the Commonwealth (1960) Chapter 4.

19 See Rautenbach and Malherbe 30. 
1250000 were Whites, whose representatives determined the constitutional framework in which the destiny of approximately 6000000 inhabitants and their descendants was to be worked out. ${ }^{20}$

The Convention, by its skilful deliberations and negotiations behind closed doors, devised a constitutional structure, which involved the reconciliation of the conflicting demands of the White inhabitants, British- and Dutchspeaking, of the four British colonies. Although the views of Africans, Coloures and Indians were clearly articulated by their leaders, these fell on deaf ears. ${ }^{21}$

\section{CONSTITUTIONAL PRECEDENTS}

At the time of the Convention, there were different constitutional traditions upon which the delegates could have drawn. In the Cape Colony there had been a long history of constitutional reform commencing from the time when the colony was autocratically administered by a virtually all-powerful governor and culminated in a parliamentary system of government, based on the cognate doctrines of Westminster parliamentary government and the Rule of Law, coupled with a relatively liberal non-racial qualified franchise. In Natal, although there was a parliamentary system of government, it was coupled to a de facto colour bar.

In the Boer Republics there were two divergent constitutional traditions, both of which involved a contentious political colour bar, based on the idea of no equality in church or state. In the Free State there had been a rigid constitution modelled on the American Constitution, the concomitant testing right of the courts and a reputation for constitutionalism and judicial independence, but in the Transvaal Republic (ZAR) there had been executive aggrandizement and judicial subordination to the executive. In the process of political and constitutional change in South Africa from 1910 to 1990, the political sentiment epitomized by the ZAR was to triumph and those of the Cape Colony were thereby inexorably eclipsed. South Africa did not follow the example of Great Britain from 1832 to 1930 with the gradual increase of the franchise, starting with the great Reform Act of 1832 and the subsequent Reform Acts of 1867, 1868, 1884, 1885 and Representation of the Peoples Act of 1918 and 1930. The latter was to enfranchise women on the same basis as men. ${ }^{22}$ South Africa was to move in the exact opposite direction by disenfranchising persons of colour in the Cape Province from 1936 to 1956.

\section{THE NATURE OF THE CONSTITUTION DRAFTED BY THE NATIONAL CONVENTION}

Unfortunately, the chief protagonists of federation like Hofmeyr, Schreiner and his articulate sister Olive, the authoress, were to be completely

\footnotetext{
20 Hepple South Africa, A Political and Economic History (1967) 99. These figures indicate the extent of the oligarchic nature of the political and constitutional plan that was devised by White South Africans.

21 Davenport 168; and see Karis and Carter 52 in fn 16 above.

22 See Poole Taswell - Langmead's Constitutional History (1929) 706 et seq.
} 
outmaneuvered by the powerful advocates of a unitary system. ${ }^{23}$ Both Smuts and Merriman, for political and economic reasons, were strongly committed to the unitary system of Westminster government. They were oblivious to the latent defects of the British Constitution and misinformed on the nature and merits of federal government. "Of the thirty-four delegates to the Convention eleven were lawyers in the Blackstone - Dicey tradition of parliamentary supremacy." 24

The Convention was also to decide on an essentially flexible constitution, giving Parliament full powers to make laws for peace, order and good government. Smuts articulated clearly and forcibly why a unitary flexible constitution was considered necessary: "What we want is supreme national authority to give expression to the national will of South Africa." ${ }^{25}$ It is tragically ironical that this "supreme national authority" was to be so effectively used by Smuts's bitter political foes, such as Dr Malan and other members of the National Party, to make deep inroads into the spirit of the Westminster Constitution he admired so much, and to further the process of constitutional retrogression to which he was unfortunately also to become party, in for instance his support for the removal of African voters from the common role in $1936 .{ }^{26}$ The Constitution was to be amended by a simple majority of each house except for the two entrenched provisions, one (section 35) protecting the voting right of all the eligible voters of the Cape, and the other protecting of the equal status of the two languages. In this respect alone the Free State tradition of rigidity was emulated. The South Africa Act was silent on the question of a testing right for the courts, which was only to receive definitive clarification in the case of Harris $v$ Minister of the Interior ${ }^{27} 42$ years after unification, giving rise to a protracted and acrimonious constitutional crisis involving the removal of the coloured voters from the common role, encapsulating fundamental issues of constitutionalism, between 1952 and 1956.

23 Thompson The Unification of South Africa (1960) 180. "Transvaal preparation, Transvaal brains, Transvaal teamwork, and Transvaal economic strength prevailed on most issues at the convention." Smuts was the chief architect of the Union of South Africa. See Hancock (1962) 268. "More than any other national constitution within the Commonwealth, that of the Union of South Africa bears the imprint of one man's mind." It is, however, highly ironical that Smuts's political foes were to use the unitary and flexible nature of the South Africa Act to implement policies, which were anathema to Smuts and his philosophy of holism ie the policy of pseudo-decolonization involving fragmentation, which is patently the very antithesis of holism.

24 Dugard Human Rights and the South African Legal Order (1978) 26. It was an age in which the British constitution and Empire were eulogized. Only in more recent times has a more critical approach been adopted to the nature of the British constitution. See Wade Constitutional Fundamentals (1980) 1: "The Blackstone-Bagehot era was the age of selfsatisfaction. Their successors today adopt a stance of fairly strict neutrality. The next era I hope will be one of the critics. Their service will be to hammer home the need for constitutional reform." See also Hailsham "Elective Dictatorship" in Hailsham The Dilemma of Democracy (1978) Chapter 20125.

25 Hancock (1962) 253. Transvaal Legislative Assembly Debates, 23 June 1908, cols 180-181 quoted in Thompson 105. The concept and materialization of the political unification of South Africa was an outward manifestation by Smuts's philosophy of holism.

26 See Hancock Smuts Field of Force Vol 2 (1968) 266.

$27 \quad 19522$ SA $428(A)$. 
The adoption of a constitution based essentially on parliamentary sovereignty was unfortunate to facilitate abuse of power and constitutional retrogression. The American paradigm, involving a federal system of government, a rigid constitution and an entrenched Bill of Rights would have been far more apposite for the culturally, religious and geographically diverse country like South Africa.

\section{THE QUESTION OF THE FRANCHISE}

The most seminal issue facing the National Convention was that of the franchise. The majority of the Cape delegates, in accordance with the Cape liberal tradition "pressed for equal rights for all civilized men". ${ }^{28}$ The delegates from the northern colonies were unanimous in their total opposition to such a reform, and also to the presence of people of colour in Parliament itself. The Natal Prime Minister, Sir Frederick Moore, epitomized the blatant racial prejudice of the Natal colonists with his notoriously racist view that "the history of the world proved that the Black man was incapable of civilization". ${ }^{29}$ The Imperial Government was indeed desirous of promoting reform in regard to the Non-white franchise, so it let it be known that the adoption of a liberal Non-white civilization test for the franchise would facilitate the transfer of the High Commission Territories to the proposed new state. This was, however, as far as the British Liberal Party Government was prepared to go in advancing the cause of reform in regard to the Nonwhite franchise. British liberals, although they were favourably disposed to persons of colour, had also vociferously opposed the Boer War and were desirous of effecting a lasting reconciliation between British and Dutch South Africans. Sympathy for persons of colour therefore, took second place. This approach was to have disastrous consequences for South Africa, as the subsequent history of the country was to prove.

Although the constitutional compromise in regard to the franchise was bitterly disappointing for the Cape liberals, it was probably, from the point of view of real politik, the only basis on which unification could have occurred. ${ }^{30}$ George Washington's famous words on the American Constitution are

28 Hahlo and Kahn 122. See Wilson and Thompson 353. "Indeed, virtually all Cape politicians professed to approve of the principle of a non-racial franchise, and during the 1907-8 election the leaders of both the political parties in the Cape Colony gave assurances that they would not sacrifice the principle of 'equal rights for civilized men' even for Union."

29 Thompson 216. This epitomised the attitude of Natal colonial authorities to both African and Indian people. The Cape was the only colony in which a meaningful liberal attitude towards persons of colour existed as far as public opinion and political leadership were concerned. President Steyn's racist views epitomised those of the White inhabitants of the former Boer republics; "when Pretorius broke the barbarians neck, God placed the Kaffers under the guardianship of the Whites, and this cannot be escaped". See "SA after 75 years" 31 May 1985 Die Burger, translated in June 1985 SA Digest 505.

30 Lewsen John X Merriman (1982) 315: "and the only practical alternative was Merriman's original compromise ..." Had the Natal politicians been more astute, a more rigid constitution could have emerged. See Thompson 191. "It will have been noted that although Natal had a weak hand she failed to make the best use of the card she held. The majority of the delegates were much more strongly in favour of a unitary Constitution than a fully flexible one, and if Natal had come in, after Steyn's impressive speech on the morning of the $14^{\text {th }}$ with a proposal to add a section to Merriman's motion, making the entire Constitution moderately rigid, it is possible that she would have succeeded." 
apposite. "If another constitution is attempted the members will be more discordant and will agree to no joint plan: a constitution or disunity is before us to choose from."31 Non-whites did, however, receive the metaphorical crumbs from the White man's table, in that they were able to sit in provincial councils of the Cape and Natal, but they could not sit in National Parliament, not even as representatives of the Cape Province, although their voting rights were protected by entrenchment. The South Africa Act, therefore, incorporated a political colour bar, which had never existed in the Constitution of the Cape Colony, and was consequently a constitutionally retrogressive development in the light of the Cape's history of constitutional reform, involving a qualified franchise.

The African People's Organization and the South African Native National Conference were profoundly perturbed by the prospect of a political colour bar and the inevitable retrogressive effect it would have on the political future of all persons of colour, and consequently they both sent delegations to London, headed by Abdurahman and Jabavu respectively, to plead for the cause of constitutional reform for their people and to object vehemently to the incipient colour bar. Schreiner, one-time Prime Minister of the Cape Colony, and champion of non-racialism, was instrumental in drafting an appeal to the Parliament and Government of Great Britain, which was read by Sir Charles Dilke to the House of Commons. ${ }^{32}$ All of this proved to be in vain. "Thus did liberals in the United Kingdom enact and like-minded men of all colours in South African willy-nilly accept a statute which they believed and prayed would lead to a victory of the Cape's well-tried civilization principles throughout the Union.,33 The distribution of power and the prospect of constitutional reform in the Union were significantly in-fluenced by the decision of the Convention to adopt a system of constituency representation or "first past the post", coupled with the "weighted rural vote, ${ }^{, 34}$ as opposed to some kind of proportional representation, as now operates in terms of the 1996 Constitution.

The Dutch parties, who were mainly representative of the sparsely occupied rural areas, cogently advocated unequal constituencies to the detriment of the urban areas, whereas the urbanized British settlers wanted "one vote one value". Ultimately, on this vitally important constitutional issue, a compromise, which was to prove detrimental to the cause of reform and the political parties sympathetic to people of colour in the urban areas, was also reached. Proportional representation, as it operates in South Africa today, ${ }^{35}$ which could have protected the position of minority groups more

3123 February 1909 Cape Times, quoted by Lewsen 320.

32 Davenport 169. The British Government was not prepared to champion the cause of persons of colour at the expense of "Anglo-Afrikaner conciliation." See Wilson and Thompson 363 and 264. In this regard Welsh 18 May 2010 Business Day points out that "[o]n 19 August 1909 the British House of Commons approved the South Africa Bill ... During the sparsely attended debates, a few MPs had spoken against the colour provisions, but for the Liberal government and the Tory opposition the uniting of Boer and Brit, which the draft constitution appeared to offer, trumped the injustices that would be done to blacks".

33 Walker 537

34 Hahlo and Kahn 123.

35 See s 46(1)(a-d) of the Constitution. See also Devenish The South African Constitution (2005) 225. 
adequately, was abandoned. Thus, electoral divisions were each to return only one member to the House of Assembly in such a way as to facilitate and accentuate a highly majoritarian form of Government, with a conservative bias.

Re-distribution was to take place at periodic intervals by means of a delimitation commission, consisting of three judges, appointed by the Governor-General-in-Council. In the process of delimitation five factors were to be taken into account, that is, existing boundaries, community or diversity of interest, means of communication, physical features and sparsely or density of population. This kind of delimitation was to favour the rural areas manifestly and ultimately to prove crucial in the political and constitutional history of the Union, but its full implications were not perceived at the time since "Fitzpatrick and the other Progressive and Unionist Members of the Convention had failed to foresee the consequences of the concessions they had made in allowing a differential of up to thirty percent in the number of voters to a division, with 'sparsely or density of population' as one of the criteria for applying the differential". In practice, this criterion was to be given great weight by all delimitation commissions, to the immense advantage of any party representing the rural voters. In all elections, this was to be a significant factor. In elections where the numerical strengths of the predominantly urban party and the predominantly rural party were approximately equal, it was to be crucial (as in 1929 and particularly in 1948 when it enabled Dr Malan metaphorically by the skin of his teeth to form a government). ${ }^{36}$ In other words, "the four colonies were to be united under a 'farmers' constitution, which would favour the Afrikaans-speaking country folk against English-speaking townsmen". ${ }^{37}$ Proportional representation would undoubtedly have been more conducive to prospective political compromise and reform in South Africa. In this regard Giliomee comments that "[t]he Alternative Vote (a form of proportional representation) ... would have rewarded moderate candidates who could draw support from both communities. The Westminster system with its constituencies (and the rule that first past the post gets everything) lent itself to group mobilization on an ethic basis" ${ }^{38}$ It is interesting to note that Smuts was initially in favour of a system of proportional representation, which he wanted written into the Constitution. ${ }^{39}$ The history of South Africa would have been vastly different had this been the case.

The strengthening of the rural vote was to prove to be an obstacle to reform since the rural population constituted the most conservative element

36 Wilson and Thompson 360 and 361. See Annual Survey of South African Law (1953) 5 and 6. Smuts was in favour of a system of proportional representation.

37 Walker 534. British South African leaders were to be cleverly outmanoeuvred by their Dutch counterparts with the result that the South Africa Act was to favour political parties enjoying overwhelmingly Dutch support ie, the National Party at the expense of all other parties.

38 See Giliomee 2 June 2010 The Witness.

39 See Hancock (1962) 258: "If he had had his way, proportional representation would have been written into the constitution of the Union."

40 See Devenish A Commentary on the South African Bill of Rights (1999) 272. Smuts lost the crucial general election of 1948 although he and his political allies had a vast majority of more votes than Malan. This reflects a political distortion inherent in constituency representation. 
of the population in regard to the issue of race, whereas many of the English speaking urban dwellers were relatively more liberal. What emerged was a written, flexible Constitution, in which de facto sovereignty (subject initially to the Colonial Laws Validity Act of 1865 and the safeguards of the Royal prerogative) was to lie with the Union Parliament and a parliamentary form of government, the executive of which has to be responsible to the legislature, thereby creating a "limited form of the Westminster system,", that was to be thoroughly "majoritarian" 42 as far as it was to relate to the White population. De iure sovereignty was to come about with the famous Statute of Westminster in 1931, an act of the British Parliament which accorded sovereignty to the Dominion legislatures. In a technical sense by virtue of the Statute of Westminster a break in legal continuity had taken place. According to Kahn there had been "a revolutionary break with the past, with subordination".

\section{THE SENATE OR UPPER CHAMBER}

A residual "federal" characteristic was manifest in the composition of the Senate which made provision for each province to receive equal representation. Natal's proposal that this provision be made "fundamental" by entrenchment was resolutely rejected. This was unfortunate, since had equal representation indeed been entrenched then the manipulation of the composition of the Senate, effected by the notorious Senate Act 53 of 1955, would have been precluded. The lack of effective checks and balances in the South Africa Act was to facilitate inroads into constitutionalism, which is a philosophy based on limited government and the Rule of Law, in the subsequent constitutional history of South Africa. It is submitted that the entrenchment of provincial powers would have resulted in a quasi-federal constitution, which would have militated against abuse of political power and the over-centralization of authority.

The intended purpose of the Senate was to protect the interests of the smaller colonies "by being composed on the basis of provincial equality." ${ }^{35}$ Eight senators were to be elected from each province by proportional representation by an electoral college to be composed of members of parliament and provincial councillors. In addition eight senators were to be nominated by the Governor-General-in-Council. Four of these senators were to be selected essentially because of a thorough acquaintance with the

41 Boulle South Africa and the Consociational Option, A Constitutional Analysis (Doctoral Thesis, University of Natal, 1984) 147. The South Africa Act was not entirely a Westminster blueprint constitution. There were important differences both in the substance and the spirit of the two constitutions.

42 Lijphart Democracy in Plural Societies (1977) 166. See also Boulle 1-4.

43 Hahlo and Kahn 150.

44 Hahlo and Kahn 123. In effect the South Africa Act was a completely unitary constitution. It had no genuine and intrinsic federal characteristics. According to Hahlo and Khan "[t]he moderate catering to provincial sentiments, such as the initial equality of representation in the Senate and the assignment of more extensive legislative powers to the provinces than are normally vested in the territorial authorities of a unitary state, should not be construed as it sometimes is - as indicative of a federal element."

45 Thompson 203. This was a token concession to federalist aspirations, since though they differed greatly in population all four provinces had the same number of elected senators. 
reasonable wants and wishes of the coloured races in order to give expression to the second purpose of the Senate, that is, "that it should be used as a means of expression of the views of non-Europeans." 46 Nominated senators were to keep their seats for a ten-year period irrespective of the dissolution of the Senate. The Senate was to be precluded from introducing or amending money bills. Deadlocks were to be resolved by means of a unicameral session at which a simple majority vote would suffice for a decision. The Senate, whose members were to be indirectly nominated, was therefore, no "Cape Legislative Council redivivus". ${ }^{47}$ The two houses were not equal in status and in a clash the wishes of the House of Assembly, whose members were to be directly elected, would prevail.

The dissolution of the Senate for a period of ten years by the Union Parliament was prohibited. This time-locked provision gave to the Constitution a federal characteristic during the first decade of its existence. In effect a unitary system of government was provided for, rather than even a weak federation. After the ten-year period, the Governor-General could dissolve the two houses simultaneously or the House of Assembly alone.

\section{THE LANGUAGE ISSUE, NATIVE AND INDIAN AFFAIRS}

According to Giliomee the most dramatic moment at the National Convention was the speech by ex-president Steyn who pleaded to place English and Dutch on an equal footing. ${ }^{48}$ As a result on this acutely sensitive language issue the National Convention eventually reached a via media. Dutch and English were to be official languages, with equal status, freedom, rights and privileges and all public and parliamentary documents were to be printed in both languages. This provision was to be entrenched and endured until the inception of the interim Constitution in $1994 .^{49}$ This was a very important development, since the Dutch culture and language, which included embryonic Afrikaans, had been at a serious disadvantage in all the colonies. Language equality was to make possible the subsequent development of the Afrikaans language and culture.

The special powers of the colonial Governors in regard to native affairs were to vest in the Governor-General-in-Council who, in addition, was to have general control over administration. This was an important development in the process of emancipation from colonial tutelage since the Governor-General-in-Council was to act on the advice of the ministers in the Union. The discriminatory laws against Asians in the Transvaal, Natal and particularly the Orange Free State were, however, to remain in force. ${ }^{50}$ This

Thompson 206.

Hahlo and Kahn 124.

See Giliomee 2 June 2010 The Witness.

S 6 of the 1996 Constitution provides for 11 official languages.

Pachai The South African Indian Question Cape Town (1971) 53. S 47 of the South Africa Act reads as follows: "The control and administration of native affairs and of matters specially or differentially affecting Asiatics through the Union shall vest in the GovernorGeneral in Council." 
was, indeed, another very unsatisfactory aspect of the South Africa Act, which was to bedevil relationships between South Africa and India in the erstwhile British Empire, and later in the Commonwealth, and finally in the United Nations. ${ }^{51}$ At the time of the Union the legendary Gandhi was agitating, but to limited avail, for the reform of these laws.

\section{PROVINCIAL GOVERNMENT}

In regard to Provincial Government, the National Convention was prepared to be innovative. The colonies were to become provinces, which were to have councils with circumscribed legislative competence in regard to direct taxation, lower education, local government and hospitals, but these provincial powers were not entrenched. There was merely a five-year guarantee on the right to legislate on lower education and compulsory reservation of bills abridging other powers or abolishing the provincial councils. The subordinate status of the Councils was evident from the requirement of Cabinet consent before provincial ordinances could come into operation. The innovative aspect of provisional government was to be found in the non-responsible and non-party executives consisting of four members and a chief executive officer, designated the administrator, who was to be appointed by the Cabinet. The provincial system had a continental flavour, particularly like that of Switzerland "and showed elements of the old Republican Grondwetten." 52 The non-party provincial Executive Committee was based on the Swiss Council of ministers, which incorporates the consociational principle of "grand coalition" aimed at effecting consensual government between leaders of competing political parties..$^{53}$ The members of the Executive Committee were to be elected by the relevant provincial council by proportional representation. This consociational feature continued until $1962,{ }^{54}$ when it was discontinued and "altered in accordance with the majoritarian Westminster cabinet system." Unity provided for in the Interim Constitution of 1993 reflected to some extent a consociational feature. ${ }^{56}$ This idea was also replicated at the provincial level, with governments of provincial unity, as provided for in the Interim Constitution.

Each council was to have the same number of members as it had in the House of Assembly, but with a minimum of twenty-five to facilitate efficient operation. The judiciary was a model between a central Supreme Court and a confederation of provincial and satellite local-division courts. At its pinnacle

51 Indians had restricted access to the Orange Free State until 1986. At the 1985 Free State Congress of the National Party it was announced that the laws prohibiting Indians from residing permanently in the province were to be repealed.

52 Hahlo and Kahn 175. This was one of the important deviations from the pristine Westminster system. See Boulle 94. Thus while the provinces were not territorial units of a federation, they were more than mere local authorities.

53 See Lijphart in $\mathrm{fn} 42$ above.

54 Act 28 of 1962.

55 Boulle 96. The 1983 constitution was to introduce the practice of a grand coalition in the Cabinet which was constituted as a tri-party coalition cabinet. See Booysen and Van Wyk Die '83 Grondwet (1994) 79.

56 See Devenish "Constitutional Law" in LAWSA (2004) par 221 and 254. 
was the Appellate Division centrally situated in Bloemfontein, with a nationwide jurisdiction, but deficient in original competency. Appeals lay from the provincial and local divisions of the Supreme Court to the Appellate Division in Bloemfontein and ultimately to the Privy Council in London. Judges were to be appointed by the executive, but enjoyed security of tenure, since they could only be dismissed by an address from both houses of Parliament for misbehavior or incapacity. Judges therefore held office quamdiu se bene gesserint. ${ }^{57}$ This meant that the concept and practice of the independence of the judiciary involving the inherent jurisdiction of the courts as it prevailed in the Westminster were to apply in South Africa.

\section{EVALUATION AND SUBSEQUENT CON- STITUTIONAL AND POLITICAL DEVELOPMENT}

The South Africa Act provided the essential framework for the government of the erstwhile Union, but as is the position in other countries, it was to be supplemented by cognate enactments, certain of which had a distinctly organic character such as laws relating to racial segregation, electoral procedures, the public service, defence and police matters. In addition, South Africa's constitutional law and framework was also to some extent complemented by the non-statutory common law, originating in judicial decisions and rules of inherited Roman-Dutch law together with the conventions of the Constitution, which formed part of the tradition and practice of British Parliamentary government. This was to prove to be an invaluable legacy. The parliament at Westminster is regarded as the mother of all Parliaments. Its internal procedures have been followed in South Africa and these facilitate orderly and democratic discourse and debate in parliament.

For the Whites of South Africa the establishment of the Union constituted a cathartic opportunity for a new beginning after the Anglo-Boer War. The position of people of colour was tragically equivocal since the South Africa Act involved a compromise, incorporating a colour bar ${ }^{58}$ between the Cape liberal tradition and the policies of segregation of the northern colonies. The Cape liberals hoped, somewhat naively, that their civilization policy would be extended to the north in a newly established Union. However, their action constituted "a huge political gamble which took little account of the strength of the South African tradition and the fear that had always lain at the back of South Africa's non-European policies ...."59 On this naive gamble hung the fate of genuine constitutional reform and advancement for the indigenous people of South Africa. The decisions of the National Convention, which

57 See Hahlo and Kahn 205.

58 See Montlante "Nation's History Implores us to Avoid 'Islands of Memory"” 31 May 2010 Business Day, who commented that the South Africa Act "marked the exclusion of African people from the main body politic of SA".

59 Walker 537. Cape liberals were to pay a very high price for this gamble, since the northern approach to the question of race was to triumph decisively. In this regard Shaw commented that "[t]he far-seeing Jan Smuts was in favour of a non-racial qualified franchise for everyone throughout the Union, but he was unlikely to get all his own followers behind him, let alone his political opponents, and he knew it." See Shaw "A Noble Vision that was Lost" 31 May 2010 The Star. 
were to be embodied in the South Africa Act, determined the distribution of power and the constitutional manner in which it could be exercised, and were to have a formative and enduring influence on the constitutional and political development of South Africa. The South Africa Act was in essence an oligarchic constitution flowing from the greatest political compromise in South Africa's turbulent history and took the form of a pactum unionis. ${ }^{60}$

The federal Commonwealth of Australia had taken about ten years to effect from the initial preparation in 1890. The Canadian Confederation had taken three years to bring about. The South African National Convention had taken less than a year to complete its work. Certain fundamental matters and in particular the vexed franchise issue had, however, been deferred for future resolution by Parliament.

The National Convention adopted a constitutional system consisting of cabinet government and prospective parliamentary sovereignty in order to resolve the perplexing problems of South Africa, the most immediate of which was the reconciliation of the interests of British and Dutch South Africans, and the most serious concerned the policies to be applied to persons of colour. The latter was to pose the greatest challenge to the Union of South Africa and subsequently to the Republic of South Africa established in 1961.

Gladstone, the British Home Secretary, became the first GovernorGeneral of South Africa. Gladstone asked General Louis Botha to form a cabinet. Jameson and Botha endeavoured to negotiate to form a "best man government"1 but to no avail. Botha then appointed his ministers from the ruling parties in the former colonies and consequently South Africa embarked upon a system of government involving potential adversarial politics. The formation of the National Party under General Hertzog was to greatly accentuate political differences, and hence encourage adversarial political strategies and a contestation style of government reminiscent of Whitehall and Westminster.

\section{CONCLUSION}

The essentially flexible character of the Constitution premised on the system of parliamentary sovereignty, by its very nature was unable to provide constitutional protection for minorities and for the vast unenfranchised African majority, found in the heterogeneous, culturally and religious diverse society that constituted South Africa. Regrettably, the South Africa Act was to facilitate constitutional retrogression and not reform.

"The founders of the Union believed that a Sovereign Parliament would be the best constitutional instrument for of the handling of these difficult problems. They had buttressed this belief with many arguments, of which some were dubious interpretations of history, others were false prophecies, and none was conclusive. In following the British example, they had ignored the fact that in

60 Wiechers 199. See Scholtz Hertzog en Smuts en die Britse Ryk (1975) 73. George explained that the Union of South Africa amounted to "grand pact, a fundamental understanding and agreement between British and Dutch elements ... in which both made sacrifices and surrenders for the attainment of a common ideal."

61 Muller 379. 
so far as the flexible character of the British Constitution met the needs of the British people, that was because they had become a comparatively homogeneous people, and their respect for constitutional conventions, for political compromise, and for personal liberty was strong enough to form an effective barrier against arbitrary action by the Government of the day; whereas the essence of the problem confronting South Africa was that her peoples were extremely heterogeneous, and the colour consciousness of most of the Whites and the national exclusiveness of most of the Afrikaners were potent enough to override any feelings they may have had for conventions, compromise, and for the liberties of others. Since a flexible Constitution provides no legal safeguards against arbitrary government, it was the very worst prescription for such a country. So long as Afrikaners remained in a political majority they would have the opportunity, and therefore, the temptation to stand together, to obtain control of Parliament, and to impose their will on the other inhabitants. A division of powers, territorially between the centre and the regions, and within the centre between the legislature, the Executive and the Judiciary, would have provided the only sound basis for concord in South Africa. The Constitution of the United States of America would have been a better model than the British Constitution."

However, Van Zyl Slabbert and Welsh adopted a different view of this regard, by stating that the prognosis for a federal constitution, as opposed to a unitary one in 1910, "is an imponderable and, besides, a federation could have entrenched racial discrimination in those provinces where it was practised. To some extent federation had this effect in the Southern states of the USA, where the clamour for "states' rights" was essentially a defence of racial discrimination." ${ }^{63}$ In contrast with the above view Gilliomee opines that "[a] federal system would have been much better for a deeply-divided nation with its ethnic and class conflicts." 64 It is submitted that in this regard the view expressed by Gilliomee is the preferable one. The 1996 Constitution provides for a quasi-federal dispensation. ${ }^{65}$ This it is submitted is preferable to a purely unitary constitution, which could facilitate abuse of political power and not accord sufficient recognition to geographical diversity and cultural heterogeneity.

The most significant constitutional developments since Union have been firstly, the meritorious emancipation of the Union of South Africa from colonial and imperial tutelage, which was consummated by the famous Statute of Westminster of 1931 and the cognate Status of Union Act of 1934. This was part of an exemplary process of constitutional reform within the British Empire and Commonwealth in which Australia, Canada and New Zealand were also involved. Secondly, and contrasting starkly with the first development, was the evolution of a policy towards people of colour. The latter involved constitutionally retrogressive measures found in the policy of de facto and ad hoc segregation, disenfranchisement, and subsequently, in the notorious policy of apartheid or separate development. This was to encapsulate, in its final stage, the policy of pseudo-decolonization involving fragmentation, and the creation of the "independent" Bantustans of Transkei, Bophuthatswana, Venda and Ciskei. Although these "states" were

\footnotetext{
Thompson 483.

63 Van Zyl Slabbert and Welsh South Africa's Options (1979) 79.

64 See Giliomee 2 June 2010 The Witness.

65 See Devenish (2005) 272 who comments that "What emerges from the Constitution approximates to a functional or structural federation ..."
} 
independent according to South African law, they did not enjoy international recognition. In the new constitutional dispensation which commenced with the interim Constitution of 1994 these "independent" Bantustans were to be reincorporated into South African land.

As indicated above, liberals in both South Africa $^{66}$ and the United Kingdom, accepted a profoundly flawed constitution which they naively believed would lead to a victory of the Cape's relatively enlightened policies in relation to people of colour. ${ }^{67}$ Although this was destined not to be the position, and progressive enfranchisement of people of colour was not to occur. Instead, the exact opposite took place, since the notorious policies of segregation and apartheid were to triumph under the aegis of Afrikaner Nationalism. Nevertheless, the act of political and geographical unification was of historic and momentous importance for both Blacks and Whites. In this regard, Welch comments that "Union created the framework for potential Afrikaner hegemony: but it also created a framework for the comparable unification of African political organizations. The formation in 1912 of the Native (later African) National Congress brought together small, provinciallybased organizations to protest against discrimination and to plead for the extension of the Cape franchise system to the other provinces." points out that the unification of South Africa facilitated the "economies of scale" 69 and promoted "a more rapid modernization of the country than might have been the case" ${ }^{\prime \prime 0}$ flowing from the common market created by the new state. This was very important since it made possible the phenomenal economic development that was to occur in South Africa, from 1910 until the present time.

It was in this politically and geographically unified state, made up by the four southern African British colonies, ${ }^{71}$ constituted on 31 May 1910, that after inordinate suffering, especially for the indigenous people, an authentic democratic government, with a non-racial and exemplary supreme constitution, encapsulating a progressive bill of rights, universal franchise based on proportional representation and a quasi-federal dispensation was to be established. This came about by means of completely inclusive constitutional and political negotiations, following from President De Klerk's epochal speech on 2 February 1990, announcing the unbanning of the

66 In this regard Shaw (31 May 2010 The Star) states that the Cape Liberals wanted a nonracial SA, but had to compromise. He states further that "[t]he pact of union was wrecked by nationalism and the racial attitudes of a large section of the white population."

67 The qualified franchise was no panacea. Furthermore, the British government acted in its own imperial interests. See Magubane "British Chose their Pockets over their Consciences in SA" 27 May 2010 Business Day. In this regard he comments that "To the British imperialist of the $19^{\text {th }}$ century, liberalism had represented that combination of the ideal and the profitable which is peculiarly English - while it stilled their consciences, it stuffed their pockets".

68 See Welch "Triumph and Defeat: Lessons of An Exclusionary Accord" 18 May 2010 Business Day.

69 Ibid.

70 lbid.

71 De Klerk poses the question "what would have happened if the British had decided to include Bechuanaland, Basutoland and Swaziland - or even Southern Rhodesia in the Union of South Africa?" See "Union Day: What it means" 26 May 2010 Daily News. 
liberation movements and the release of Mandela. ${ }^{72}$ This resulted in an comprehensive political settlement, in which a charismatic and saintly leader, in the person of Nelson Mandela, was to be democratically elected as the President of South Africa. He was to selflessly promote racial and political reconciliation and leave South Africa an invaluable legacy in this regard. Mandela demonstrated that genuine reconciliation is a process. It is not merely one set of actions that takes place at one period of time. It must be a continuous process that must engage and benefit us on a daily basis. It involves all the people of South Africa, but in particular the political, religious and social leaders. Although reconciliation obviously requires forgiveness and penance, it requires an acceptance of differences, mistakes and failures. In effect, a real acceptance of the rainbow nation with its great diversity which is both a source of richness, but also involves an enormous challenge in order to reconcile infinite needs of a democratic majority with minority fears and aspirations must occur.

One must as a nation learn from its history. The South Africa Act and its political and constitutional consequences can illustrate to us important lessons in relation to, inter alia, political nation building, comparative constitutionalism, the Rule of Law and different models of government. In this regard Deputy President Kgalema Motlante ${ }^{73}$ makes the following perceptive comment:

"As South Africans, we need to own up to this collective history. Whether odious or admirable, all sections of our society have played a part in the development of our history, that ultimately shaped the character of modernday SA. This shared history must help us evolve a common destiny, based on the reality that our future is, in any case, indivisible."

72 See Devenish "The Making of the interim Constitution" 1997 THRHR 613.

73 See 31 May 2010 Business Day. 